\title{
European Somali Children Dumped? On families, parents, and children in a transnational context
}

\author{
Dumpning av europeisk-somaliska barn? Om familjer, \\ föräldrar och barn i en transnationell kontext
}

\author{
Sara Johnsdotter*
}

Department of Social Work, Faculty of Health and Society, Malmö University, Malmö, Sweden

Transnational familyhood is a challenge to western societies, whose implementation of legislation generally works with the assumption that families are nuclear and situated within a nation state. In the present case study, Somali transnational family organisation is juxtaposed with the western nuclear family model to illustrate the basic differences between the models. The mobility of children in the Somali family system is discussed in relation to child protection in European societies. Cultural variation in family organisation needs to be further discussed in societies that claim to be multicultural. The nature of child protection interventions by social workers will depend on whether society declares universalist or cultural-relativist values as more important.

Keywords: child welfare; Somalis; family relationships; migration; immigration; transnationalism

Transnationella familjer utmanar västerländska samhällen, eftersom dessa länder tillämpar en lagstiftning som utgår ifrån antagandet att familjer är kärnfamiljer som vistas inom gränserna för en nationalstat. I artikeln jämförs den transnationella somaliska familjeformen med den västerländska kärnfamiljsmodellen för att påvisa de grundläggande skillnaderna mellan modellerna. Hur barn är mobila i den somaliska familjemodellen diskuteras i relation till socialtjänstinsatser i Europa. Kulturell variation i hur familjer organiseras behöver diskuteras mer i samhällen som säger sig vara mångkulturella. Interventioner för barns bästa kommer i slutändan att präglas av huruvida samhällen anser att universalistiska eller kulturrelativistiska värden ska väga tyngst.

Nyckelord: Socialtjänsten; barnavårdsutredningar; somalier; familj; migration; invandring; transnationalism

*Email: sara.johnsdotter@mah.se 


\section{Introduction}

In the first years of the new century, a new phenomenon was described in public discussion in Sweden, the existence of so called 'dumped' Somali children. The expression applies to Somali children, primarily teenagers, who are sent back to East Africa while their parents and siblings stay on in Sweden.

What triggered the public discussion was, among other things, a televised documentary about two Swedish Somali teenagers, a brother and a sister, who had been left in Somalia and now struggled to find a way to return to Sweden. The documentary, 'Dumped in Africa' (SVT, 2005), was produced by a highly prestigious editorial board at the national broadcasting company. The story elicited fierce reactions from the general public. During the days following the broadcast about Ahmed and Nimo, a large number of letters were posted in the discussion forum of the broadcasting company's website. Most of the people wanted to send money to help Ahmed and Nimo with the cost of tickets to Sweden, and, actually, they returned to Sweden only a few days after their case had been highlighted on television.

Several viewers had things to say about Ahmed's and Nimo's parents as well as Somali parents in general-the documentary bore witness of Swedish Somali children striving to get back to Sweden via the Swedish embassy in Addis Ababa. It was asserted that hundreds of such young people were from Sweden, while there were thousands who had been living in other western countries before they were sent to East Africa. ${ }^{1}$ Somali parents now were pictured in public as being bad parents, willing to 'dump' their loved ones on the street: 'I can't understand how parents can dump their own flesh and blood in this way' one of the agitated viewers admitted (SVT website, 2005).

As a result of the heated debate that followed the publication of this situation, Swedish social services had to revise their protocols for handling 'displaced' Swedish Somali children, as a result of the fact that the Social Services Committee in charge was formally criticised for their handling of the case. ${ }^{2}$ In addition, Swedish legislation regarding the issuing of passports was changed so that Swedish passports could be issued to a minor even if the legal custodians of the child objected. ${ }^{3}$

The aim of this paper is to discuss some cultural variations in family organisation and parenting in relation to current theoretical debate regarding international and transnational social work. Hopefully, a juxtaposition of divergent ideal models-in this case the ideal 'Somali' family as compared to the ideal 'Swedish', or western, family-may render a clearer picture of the phenomenon of the so called 'dumped' children. Although some empirical examples will be presented and discussed, focus here will be on cultural constructions, that is, ideal and ideological concepts of family relations.

This implies a level of generalisation, where the enormous variation among both Somalis and westerners is disregarded. However, as Canadian anthropologist Janice Boddy has pointed out, 'to avoid overstating contrasts one must generalise, to avoid overgeneralizing one must differentiate' (Boddy, 1997). Here, some generalising will be done in order to contrast these family systems and illustrate some basic differences, and this will thus be done at the expense of all the variations and idiosyncrasies within the groups. For instance, compared to family organisation in other European countries, Swedish society (like the other Scandinavian societies) moulds the 'typical family' in a certain way through national policies 
on gender equality, state child care, subsidy programmes, and social welfare institutions, primarily focusing on the individual. Yet, the 'typical Swedish family' is part of a more general family pattern, typical of western family organisation, known as the 'nuclear family' (Therborn, 2004).

Issues related to cultural variation of family models are of vital importance to social work in Europe, which currently primarily serves the purposes of a certain cultural-specific family model: the western nuclear family in its generalised form. In this paper, I will start with a brief summary about how transnational familyhood is dicussed in the academic field and then present a case from my own empirical data to show how transnational familyhood may work at the individual level. Thereafter, I discuss the western cultural construction of ideal families in order to contrast it to Somali ideals as regards familyhood and child rearing. The fear of loss of control among Somali parents living in exile in western countries is discussed. Finally, I suggest some implications in relation to current theoretical debate in social work.

\section{'Mobile' children in transnational families}

It is common to think of a family as an entity enclosed in one household, where family members who interact daily live under the same roof (Bryceson \& Vuorela, 2002). In contrast, the transnational family is characterised by close relations that are maintained also transnationally:

'Transnational families' are defined here as families that live some or most of the time separated from each other, yet hold together and create something that can be seen as a feeling of collective welfare and unity, namely 'familyhood', even across national borders. (Bryceson \& Vuorela, 2002, p. 28)

Transnational familyhood is often related to migration (e.g., Gardner 2012; Ní Laoire, Carpena-Méndez, Tyrrell, \& White, 2010). Mobility and migration abroad are taken-forgranted aspects of life in some cultural contexts, and this will have an impact on children (e.g., Akesson, Carling, \& Drotbohm, 2012; Coe, 2012). In some contexts children specifically are the ones on the move (e.g., Olwig 2012, who has studied children's transnational mobility between households in the Caribbean migration tradition; Ní Laoire et al., 2012; Orellana, Thorne, Chee, \& Lam, 2001).

Sending children back to the country of origin of adult kin, or the threat of doing so, has been discussed in the literature as a 'deliberate strategy of child rearing' (Orellana et al., 2001, p. 572; see also Falicov, 2005). In such cases, it is seen as a means to foster children or youth, whose development trajectory is regarded by adults as 'off track'. A general tendency in the research field of transnational mobility of children is to highlight the fact that children are subjective beings in their own right, with agency and decision-making capacity, and yet positioned in a web of wider family power dynamics (e.g., Ní Laoire et al., 2010; Orellana et al., 2001; White, Ní Laoire, Tyrrell, \& Carpena-Méndez, 2011). Further, children are parts of 
larger family networks, where strategic decisions concerning children are taken for the benefit of the collective (Orellana et al., 2001).

This article aims at providing a contribution to this research field about children's mobility in a transnational context, and a discussion on how this issue is of relevance to social workers in Europe.

\section{Method}

This study was exploratory and open-ended; therefore no detailed study design was decided beforehand. This approach is in line with what has been named 'naturalistic inquiry' (Lincoln \& Guba, 1985). The study builds upon interviews with Swedish Somalis in 2005-2006. Informants were recruited through snow-balling. I made an effort to include both older and younger interviewees, as well as to achieve a variation regarding age and gender. The interviewees had different backgrounds as regards age, clan affiliation and level of integration in Sweden. However, most of them had lived in Sweden for many years and were able to compare and discuss the different family models with ease. Most interviews were conducted in Swedish and a few in English. Most interviews were semi-structured and taped, while other interviews were more of informal conversations where I took notes. Almost all of the interviews were individual, while on one occasion a discussion involved two women and two men (they took turns in translating the ongoing discussion from Somali to Swedish into my tape recorder). At least ten interviews were extensive and taped while many other interviews were more like informal but informative conversations on these topics. All the taped interviews were transcribed and when notes were taken, these were written out fairly immediately after the conversation.

Before the interviews took place, the aim of the study was described to the interviewees: it was explained that this study was about different family models and aimed at a deeper understanding of the implications of these variations for a Somali family living in a western country like Sweden. Everyone was informed about their right to refrain from answering questions they did not feel comfortable with and to terminate the interview or conversation at any time without further explanation.

All interviews started with basic questions about 'typical Swedish families' and 'typical Somali families'. New questions were continuously formulated during the study, since new themes were presented by informants as the study went along. When informants were given the opportunity to discuss what other informants had conveyed, a complex picture of consistencies and variations arose (e.g., Agar, 1986). Guiding questions during analysis of the interviews concerned constructions of what is an 'ideal family' and variations in ideas of what is in 'the best interest of the child'.

Analysis of the interviews was made according to classical anthropological tradition: 'Deciding on themes or codes is an unmitigated, qualitative act of analysis in the conduct of a particular study, guided by intuition and experience of what is important and what is unimportant' (Bernard, 1996, p. 10). In terms of the analysis model this procedure is in line with 'naturalistic inquiry' (Lincoln \& Guba, 1985). 


\section{Somali familyhood across borders}

Somali familyhood is characterised by transnationality (Al-Sharmani, 2006, 2010; Engebrigtsen, 2007, 2011; Peutz, 2006; Tiilikainen 2011). The transnational character of the global clan network is essential for the formation of strategies: Somalis maintain family relations across borders, struggling for better future opportunities for their families despite the civil war in Somalia, deportations from western countries, and other forms of hardship.

The authentic case story below illustrates how family relations are maintained transnationally through some episodes in a family originally from Somalia. In addition, the case describes encounters with authorities representing a structure promoting nuclear families. All episodes are described in one person's perspective, Amera's, and hence convey only her version. To follow the story fully, one needs to know that Somalia is a patrilineal society: the blood ties run through the paternal side of the family and, hence, clan affiliation is inherited from the father:

Rooble, Amera's older brother, married a woman of another clan in the 1980s. They had two sons, Daud and Asad. When the youngest boy Asad was one year old, his parents divorced. Amera had already then begun to show this boy special attention: 'Even when I was a student [in another part of the world] I took special care of him, I bought toys and stuff for him. He still lived with his mother then.'

The mother of Daud and Asad moved to Saudi Arabia: 'When she divorced, she left the children with their father. She was young and wanted to work.' There she married a man of her own clan. Amera's mother, the boys' paternal grandmother, took care of Daud and Asad. Sometime after that Daud was taken to live in a refugee camp, by his maternal grandmother.

Amera decided that she would take care of the younger brother Asad: 'My mother was getting old. I decided I had better take care of him.' Amera then had a two-year-old child of her own, and she was expecting her second child. She had left her own son with her mother when she went to Sweden applying for asylum. When her husband was about to reunite with her in Sweden some years later, she asked him to bring both their son and her nephew Asad: 'I thought he must have a good life and good education. The same as for my own children'. Asad was seven when he moved to Amera. Some years later his father died in Somalia.

One night when Asad [now a teenager] was out hanging with friends, he did not come back until after midnight: 'I was so scared... I didn't know what has happened... so when he turned up, I started yelling at him, "Why are you so late?" Asad responded to Amera's rage by pushing her aside, declaring he wanted to move to his mother. Amera became afraid of him; he had grown so tall and big, and she was afraid that he may hit her, and that he would become a bad example for her other children. The social authorities were involved, and during a meeting Asad spoke in terms of 'her [Amera's] children':

So they wondered... 'What does he mean? Is he not your son?' they asked me. So I told them: 'You should ask him and not me. My son he is.' To me there is no difference. That's actually the way I feel. He is my son. We share the same blood. I said to the social authorities: 'Ask him, he speaks Swedish well.' And I said to him in Somali: 'It's okay with me if you tell them 
who your father and mother are. I don't see any problem if you do that. But they will never hear from me that you are not my son... because you are. So... If you want to, you can tell them the truth and I can explain to them why I brought you here. Then I will talk about it. But I won't forestall you.' But he never said... he never called me Aunt or anything like that. He has always called me Mum.

Amera told Asad that they could go and see his mother. They spent ten days in the UK. Something went wrong when Asad was to spend time with his biological mother: Asad's mother would leave the house with her other children and refer Asad to his 'cousins' living nearby, that is, people from his own clan. 'And he knew nothing about this. We never taught him that 'you belong to this clan and your mother to that clan'... So she left him with people that even though they were from our clan, they were unknown to him': Asad moved to another paternal aunt, Amera's older sister in the US: 'It was Idil's turn to take care of him. I had done my job for many years.' Asad, who today is a young man studying at a US university, still keeps in touch with Amera, even though it is not as often as it used to be. Still he calls Amera 'Mum', while he addresses Idil by saying 'Aunt'.

Some themes are evident in this story and these themes presented themselves also in many other interviewees' stories. Children's lives are affected by how clans are organised - children belong to their father's clan even when they grow up in families of some other clan. This is observable in the story above: Asad does not share his mother's clan affiliation, and this fact also impacts on his life when he lives in Europe. Although many Somalis in western contexts are hesitant to talk about clan affiliation to outsiders, this system is everpresent in their daily lives and is crucial for Somali identity construction (Johnsdotter, 2002; Tiilikainen, 2007).

Another theme introduced in this story regards norms relating to motherhood. Asad's mother leaves her children with relatives in Somalia in order to work abroad. This is not unusual among Somalis, and thus not in itself a choice that would lead to stigmatisation or challenges from others that she would be a 'bad mother'. (Transnational parenthood, socially accepted in contexts where many people migrate, is increasingly discussed in the literature; see e.g., Akesson et al., 2012; Falicov, 2005, 2007; Olwig, 2012; Orellana et al., 2001).

In the social services office, it is disclosed that Amera is not Asad's biological mother. Here we can see a clash between a system registering family relations and assuming certain biological relationships (as long as there is no information revealed leading to a questioning of these relationships). In this situation Amera insists that her motherhood is valid, albeit it does not come in the form of the closest possible biological relatedness. She declares that her care for Asad is 'the same as for her own children', and in doing so she conveys an important aspect of Somali shared parenthood: the prescribed norm is that the one with custody of children has to make sure that all the children, irrespective of biological relatedness to the parents, are given the same opportunities.

Parents may leave the custody of their children to relatives if they have plans that prevent them from rearing children. The biological parents are supposed to show care and to feel the responsibility for their own children even though these children are raised in other families during a shorter or longer period of time. When fostering somebody else's child, one is ideally supposed to treat that child as one treats one's own children, and if problems arise a 
viable solution is to send the child to another household. Before these themes are discussed in more detail, the ideal western family model is considered below. The purpose of this juxtaposition is to show that western family organisation, just like Somali family organisation, is a cultural product-irrespective of how 'natural' it seems to those of us who grew up in a western context.

Many Somalis talk about the 'Swedish way' of rearing children as peculiar and sometimes even harmful. One such opinion is the one asserting that the Swedish day care system is reprehensible, since leaving the children to outsiders does not create any bonds between parents and children. ${ }^{4}$ This family model, it is claimed, creates children who leave their parents early in life to be independent—and such an upbringing makes family bonding weak.

The 'Swedish' family model can be said to be part of a larger family system stressing the importance of individuality and autonomy, in contrast to models focusing on collectivity, or relatedness, and interdependence. The basic orientations can be summarised as follows:

Individualization implies that the discourse of individual rights and liberties has become hegemonic, and that there is a foregrounding of specific value concepts such as freedom, rights, choice, independence, individuality, uniqueness and achievement, at the expense of concepts such as dependence, obedience, duty, togetherness and community. (Gullestad, 2003, p. 51)

The interdependence model is more likely to appear in rural agrarian societies in the world, and also in urban groups with a low socioeconomic status. In this model children, while young, are also expected to contribute to the family economy and provide economic security for their parents when they reach old age. Obedience is important in child rearing, to avoid raising independent children that will look after their own selfinterest rather than the collective's best interest. Such independence and autonomy would threaten the core of the family model (Kagitcibasi, 2005; see also Bornstein, 2012; Renzaho, Green, Mellor, \& Swinburn, 2011).

\section{The western family and the child as a primary love object}

The prototypical western family is a structure of independent individuals in a system where families, in turn, are independent of each other. The essence of the family concept is the nuclear family, that is, one or two parents with one or more children in a household. Generally, only two generations live in the same household, and emotional and material resources are canalised towards the children and not the elders (Kagitcibasi, 1996, p. 84). This family model is characterised by a permissive child rearing style in contrast to the more authoritarian prevalent in family models oriented toward interdependence.

Late modernity has been characterised by a loss of traditional values, anchored in religion for instance, and western people now seek other values to make life meaningful. Baumeister and Muraven argue that 'domesticity, including marital love, privacy for the nuclear family, and especially parenthood' (Baumeister \& Muraven, 1996, p. 409) are 
increasingly appreciated to convey a sense of meaning. The self as a project has become central, at the same time as the family is in focus:

Pursuing love, caring for family members, and doing what is best for the children are all widely accepted as ways of doing the right thing - and they do not require further justification. [...] Self and the family are therefore two of the most powerful modern values. The potential for conflict between them is therefore one important aspect of the modern context for identity. (Baumeister \& Muraven, 1996, p. 411).

The former social and economic functions of children in the West have been altered (e.g., Beck \& Beck-Gernsheim, 1995). Generally speaking, children brought up in the western family model receive a historically unique amount of love and attention, since the supplying of love, besides matrimonial intimacy, has come to be seen as 'the focal meaning and purpose of the family' (Baumeister \& Muraven, 1996). The German sociologists Beck and BeckGernsheim reflect upon the fact that nativity may fall, but that children have never before been as important as now in our society:

The child becomes the last remaining, irrevocable, unique primary love object. Partners come and go, but the child stays (Beck \& Beck-Gernsheim, 1995, p. 37). ... the nuclear family is becoming excessively emotional, and the atmosphere in the small family circle dangerously over-heated. There is a similar greenhouse effect in many adult partnerships, but in that case if pressure rises too high there is a safety valve: one can at least consider separation. There is no divorce from a child, and that is the decisive difference; no legitimate escape route offers itself, and society categorically states that 'parents love their children'. (1995, p. 139, emphasis added)

They discuss further implications of this, which will not be considered here. My point is to highlight the constitution of the western nuclear family and its prevailing ideology of parentchild relations.

\section{The Somali family model and the mobility of children}

The Somali family is, ideally speaking, much more extended than the prototypical western family (see, e.g., Boyle \& Ali, 2009; Tiilikainen, 2011). Every household is in constant interaction with other families, primarily along clan lines. The basic family model is clearly based on collectivity and has a strong emphasis on interdependence between relatives and across generations. In addition, there is the idea that children are mobile between households within the family.

Many Somali families present foster children as biological children when moving to western countries, since they perceive that this arrangement is required in societies where strictly biological bonds are emphasised. In such cases, the foster children are given the foster father's first name as a surname ${ }^{5}$ and this creates a dilemma: one must not give a child a false name according to Islamic principles. Many Somali parents are fearful that the truth about the lack of close biological bonds will be disclosed by authorities, and this would have the 
consequence that these parents have failed in protecting the children for whom they have assumed responsibility.

When I have asked Somalis how common it is to have foster children in a family, everyone replies that all families, at some point, have one or more children in foster care while some of the 'own' children may be placed in some other family, temporarily or permanently. A Swedish Somali man in his 50s, who grew up with cousins ${ }^{6}$ (technically) as brothers and sisters (socially) and in periods has raised both his own children and others', explains:

To us, culturally, to state the exact difference between biological parents and parents... it is wrong. An adult relative is a parent to the child. It does not exist in the history a family where only the own children have been raised and no others, in our country it does not exist. The decision seems to be made by all involved, where all adults have a responsibility to see to the best interest of the child. It may be the sending part saying that, 'I want her to go to school there, can she live with you?' as well as the receiving part suggesting, 'Let him come and live in my house, I'll take care of him and make sure he receives proper medical care'. Both men and women are said to be involved in decision making, and married couples are supposed to agree: 'My husband has the possibility to say no. But everyone knows what our responsibilities are. He would have done the same thing. If he took that decision, I would support him', says a woman in her 40s.

Often the discussions are framed in terms of 'the child's best interest'. This seems to weigh heavier than what can be labelled the biological parents' emotional bonds to the child. Often a child is seen as belonging to an extended family rather than to individual parents (see also LeVine \& LeVine, 1981). A man talks about his brother (who is actually his 'cousin', but who grew up with him), whose only child he once wanted to take with him to Sweden when fleeing from the war in Somalia. According to this man, his brother and sister-in-law's emotional bonds to their daughter were of little interest in the light of what he himself could offer her in terms of security and education if he raised her.

However, children's mobility takes place also for much less dramatic reasons than war. Children move between households for many reasons (see also Al-Sharmani, 2010). Schooling and education seem to be important reasons. Nomads often send children to relatives in town for education. Some sickly town children are sent to 'camels, nomads' (and the healthy camel milk) to strengthen them. Children are mobile within the Somali nation, but transnationally as well, since the Somali clan structure is increasingly global today.

What restrictions are there, when it comes to sending a child somewhere? According to a woman in her $60 \mathrm{~s}$, a child would only be sent to a mother, father, sister or brother. But many others do not agree that potential care-givers are so few. Anyone related to the fatheraccording to the Somali principle of patrilineality — may take over custody: 'The father's side has no limitation. A child can be sent to any cousin... [with a common ancestor] twenty generations back'. Close relatives of the mother are generally seen as potential foster parents. It is also a matter of who will take care of the child on a daily basis: a paternal aunt, related in blood, is expected to take better care of a child than a maternal uncle-since in everyday life 
it is his wife, possibly clan-unrelated to the child, who will spend the most time with the child.

I ask a twenty-five-year-old Swedish Somali woman if there is any stigma associated with growing up outside one's biological family:

No, not in that way. [Pause.] But it depends... when I think of it. If that family is your own kin, then... absolutely not. But if you belong to another clan... if you came into this family in some other way than blood relations... it may work as a stigma. ... that she is in fact not part of the family.

Others say that the outcome depends on what kind of family takes care of the child, but also how closely related they are. The norm seems to be to keep in touch with one's biological children, an interaction facilitated today due to fast communications and the invention of programmes like Skype (see also Baldassar, 2008).

It is reported in several studies that childrearing in Africa, generally speaking, is more authoritarian than in the West (see e.g., Bledsoe, 1990; Kagitcibasi, 1996, 2005; LeVine \& LeVine, 1981; Renzaho et al., 2011). A man in his early 50s reflected upon the differences between 'Somali' and 'Swedish' childrearing styles and argued that Swedish or western ways are counterproductive when it comes to creating a strong person, the goal of Somali upbringing:

We are the ones creating very hard strong individuals. We do practise spanking, for instance, we spank children, in school, at home... It is not because you don't like your children, on the contrary, but one has the intention to raise them strictly. You want that person to stand strong as stone. Strong.

While recent studies from the UK, including African families, show that there are no significant differences between ethnic groups with regard to punitive punishment practices (Bernard \& Gupta, 2008), the situation may be different in Sweden, where all forms of physical punishment of children, including spanking, slapping or pinching, were criminalised in 1979 (Children and Parents Code, Chapter 6, Section 1). Kagitcibasi (1996) emphasises that children experience their parents' childrearing style in relation to the wider cultural context. A strict, harsh parental control may be seen by the children as 'normal', and therefore 'good': 'When the child who is exposed to it compares herself with other children, she finds that she is not different from them, that is, she is not rejected by her parents' (Kagitcibasi, 1996, p. 21; see also 2005). Thus, we cannot assume that all Somali children see a 'harsh' upbringing as wrong or lacking love. When asked if 'dumped' children do not feel 'unloved' by their parents, a woman, who was about 20 years old, replied:

Isn't it so Swedish to be that sentimental... well, I hope you don't mind I say so, but it is so typical Swedish. [Gives a sigh.] Please... I have lived here in Sweden for almost twenty years, and my parents, well, they love me, but... It is just so typical Swedish to be that emotional... just to think in those terms... You see, it is not in our culture to think, 'Doesn't this or that person love me?' 
Her description of the culturally legitimate ways for Somalis to express emotions should be understood in relation to the culturally legitimate ways of expressing emotionality in the West. The imposed emotionality in the West is as much a cultural construct as the Somali. Some scholars, such as Beck and Beck-Gernsheim (1995), argue that emotionality in the West has reached levels that lead to increased risk of a greenhouse effect in many families since the western nuclear family is a very cramped social sphere.

However, the picture is complicated by the fact that Somali children are confronted with contradictory childrearing styles in Sweden. In social institutions and among friends of Swedish origin, they may see other kinds of adult-child interaction, and this may create confusion over what is really 'normal'. Some interviewees stated that it is easier for young children, because they learn soon that there are two conflicting systems — one at day-care and one at home - and they learn how to navigate in both systems. They know when they are expected to show self-assertion, and when they are expected to listen and obey. For older children, the situation is more complex and the adaptation may be more difficult. Many Somali teenagers who arrive in Sweden perceive it as a society lacking rules and norms, as many interviewees attest.

Even though children may internalise two conflicting norm systems and learn to navigate between them, this situation may create frustration and tensions when the young person is to form an adult life, where he or she is expected to consider both collective responsibilities and individual drives and goals (Engebrigtsen, 2011). On the other hand, the ability to navigate between two different norm systems may also result in positive experiences among young western Somali people, allowing them to feel resourceful and capable (Rousseau, Said, Gagné, \& Bibeau, 1998).

\section{The fear of loss of control}

Many Somali parents experience that there is a loss of authority in relation to the younger generation in Sweden (Johnsdotter, 2002). Griffith (2002) reports the same situation in the UK; that Somali parents experience that they 'lose control' of their children and teenagers. Many interviewees pointed out that there are huge risks for young people in the West and that parents have to act forcefully if 'the children start using drugs, start going downhill'. To take action can also be about sending the child to Somalia, where everyday life ideally is characterised by Islam and where there are no (heavy) drugs.

This risk of being sent away is present especially for children who live in foster care. So called 'segmented parenthood' (Akesson et al., 2012 suggest 'the transnational fostering triangle'; Goody, 1984), which is practised by Somalis in their system of perceiving children as 'mobile', is also about allocation of responsibility. The foster parents are responsible for seeing to that the children in their care develop into good and well-educated adults. If things seem to go wrong, they cannot be passive onlookers; they must take action or offload the responsibility:

So if the children do not develop in the way they expect [being studious in school, being good Muslims, being obedient]... if they don't, they [the foster parents] feel obliged to return them 
[the children] to their mother or father or someone else. They are afraid to be accused, 'They hadn't the possibility to take good care of him. Why didn't they let him come to me, if they couldn't care for him in a good way?'

However, also biological children are sent to Somalia, or Egypt or some other country, for a period, either to 'get back on track', to 'get to know their culture' or to improve their language skills (see also Tiilikainen, 2011). Among those I have talked to, I find cases including everything from voluntary and willingly moving to cases where children were forced to move. Obviously there are also cases where children have been tricked into making the trip and where they have been unexpectedly abandoned among people who they considered to be total strangers. An older man described that situation as a kind of emergency strategy: 'No parent is willing to wait and see [if there are serious problems], and then watch their child become a junkie living in the street'. The strategy to send children away to the home country is not unique for Somalis, also in other ethnic minority groups rebellious teenagers are sent away in order to shelter them from bad influences (Falicov, 2005; Orellana et al., 2001). This may be a hazardous strategy in a politically unstable country such as Somalia. In response to this objection, my informants stressed that some parts of Somalia are safer than others, and also that a forced trip is a sign of desperation.

There is yet no systematic research on how this system of mobility of Somali children is experienced by concerned children. Griffith reports from the UK that many young Somalis associate their parent's home country with 'warfare, famine and general savagery' (Griffith, 2002 , p. 118). For those youths a forced stay in Somalia possibly would be something of a nightmare. A study about children moving between their homes in London and Bangladesh showed how the children had marked experiences of changed social status in the different physical and social contexts, being 'emplaced and marooned in deprived locations' (Gardner, 2012, p. 907). Further, even though the parents - foster parents or parents in a strict biological sense - send the child to relatives that they know and trust, these people may be perfect strangers to the child. However, the parental generation's view may also be reproduced in some young Somalis. A twenty-year-old woman declared that the strategy to send rowdy teenagers to Somalia is valuable: 'if my children mess up their lives, I would take them home, to teach them some sense and what it is like to live... I mean really live, to see every day how people go begging.' Thus, also young Swedish Somalis may see advantages of sending children and youths back to Somalia in the future, pointing towards a possible continuity in transnational familyhood also among some people who grew up in Sweden.

\section{Current debate in social work: culturally appropriate practice versus universal values}

This empirical case regarding children's mobility in the traditional Somali family system evokes certain questions in relation to social work practice in European welfare institutions: Is a family system including mobility of children and segmented parenthood incompatible with existing child welfare principles dominating in Europe? Or, should social work practitioners aim for culture-sensitive adaptation to multicultural realities, in which culture- 
based non-familiar ways of caring for children are embraced even when they challenge basic western ideas about 'the best interest of the child'? Or, should every case be assessed and handled as a unique case, depending on circumstances? That would imply that some cases of sending back a child to Africa are seen as legitimate, and others as reprehensible and therefore a cause for intervention by child protection services.

Questions of this kind tap into a current theoretical debate in the academic field of social work. How to deal with cultural variation in social work is discussed both in relation to the implementation of (western) social work in non-western parts of the world, and as an issue of increasing relevance for social work in multicultural western societies (e.g., Gray \& Coates, 2010; Gray, Coates, \& Bird, 2010). A movement aiming at implementing global standards in social work education has led critics to conclude that such attempts are imperialistic:

Cultural relevance is forcing us to entertain the idea of multiple social works and social work knowledges, rather than a universal profession with universal values. The latter amounts to a McDonald's-ization of social work, a one size fits all approach that is paradoxical in a profession which values and extols diversity. (Gray, Coates, \& Bird, 2010, pp. xxv-xxvi)

The critics argue that most social work practice is founded on western assumptions and beliefs, such as an emphasis on individualism and materialism, and, as a consequence, overlooks the realities of the social situation in which many people live their daily lives. Pointing out that many immigrant and refugee communities are characterised by other social values, they claim that the profession now must 'question the primacy of Western (modernist) values and to rethink just what is universal' (Gray \& Coates 2010, p. 21, emphasis in original). The risks inherent in a social work implementing western-based ideas about 'the best interest of the child' among culturally different groups are illustrated, for example, by the child protection interventions among Aboriginals in Australia during the first half of the twentieth century, where many children (now known as the Stolen Generation) were separated from their families and taken into custody (Dockery, 2010; Thorpe, 1994).

On the other hand, other cases in the history of social work serve as warnings against culture sensitivity taken too far, in cases where lack of intervention has ended up in disaster. One of the most well-known cases in Europe, the murder of black African Victoria Climbié in the UK in 2000 (see, e.g., Balen \& Masson, 2008), also had a cultural component (Raman $\&$ Hodes, 2012). In fact, "inability or unwillingness to distinguish "abuse" from "cultural practice"' (Barn, 2007, p. 1429) may end up in 'laissez-faire' practice with disastrous consequences for concerned children (Barn, 2007; Williams \& Soydon, 2005). Critics of such tendencies in social work practice advocate a perspective focussing basic human rights (e.g., Ife, 2001; Webb, 2009), often referring to the UN Convention on the Rights of the Child (e.g., Trygged, 2010; Winter, 2011).

Beside theoretical and ideological concerns along a continuum, where the extremes celebrate either culture relativism or universalism as the guiding principle for social work practice in multicultural societies, practical issues come to the fore in the dealing with cases involving transnational familyhood. The fact that social welfare systems exist within the constraints of nation-state boundaries has practical implications for social work with 
transnational families, since local practice may have cross-border and international dimensions (Lyons, 2006; Furman, Negi, Schatz, \& Jones, 2008). This was demonstrated in the Swedish case: it was explicitly stated from the national supervising body (the Swedish Board of Health and Welfare), that professionals working with child protection services are to interpret the Swedish Social Services Act as applicable also abroad. Consequently, if a Swedish Somali child in East Africa contacts the social services in Sweden asking for aid, the authorities have the responsibility to see that a passport is issued and that the child or young person is brought back to Sweden and taken care of in accordance with regular child protection routines.

Several authors highlight the balancing act involved in assessment of child protection cases in which (non-western) culture is a dimension: it is a matter of respecting people's world views and cultural practices, 'whilst at the same time not losing sight of children's welfare needs' (Barn, 2007; Bernard \& Gupta, 2008, p. 488; see also Williams and Soydon, 2005; Lyons, 2006).

\section{Conclusions}

In summary, we can conclude that this phenomenon - that some children and young people are sent to Somalia against their will, the so called 'dumping' — is a small part of a much bigger picture. It is common that children migrate between relatives within the global Somali clan system, and this mobility takes place in order to optimise the children's future prospects. 'The best interest of the child' is the stated intention from a parental perspective; however, this view may be in conflict with the child's perspective. Further research is needed to reach a deeper understanding of different views of this phenomenon, including the issue of how the clash of contradictory ideal family models is experienced by Somali children and teenagers in western settings.

The way the western model is seen as self-evident in European countries is obvious for instance in family reunification policies; to an increasing degree, European countries use DNA testing to establish family relations (Andrijasevic \& Walters, 2010; Bingham, 2013). These procedures put close biological relatedness in the centre, despite the fact that concepts of what constitutes a 'family' vary extensively in different parts of the world. These issues are more relevant than ever at a time when the disastrous sociopolitical situation in Somalia forces a second wave of thousands of refugees to apply for asylum in Europe, as well as in other western countries.

On one hand, an extreme universalist would argue that child protection must be practised according to universal standards of what is in the best interest of a child and that ethnic background of the child is of little importance in this context. On the other hand, an extreme cultural relativist would contend that what is in the best interest of a child will vary with ethnic background due to variations in culturally specific ideas about familyhood, and that social services, such as child protection must take those variations into consideration. The nature of interventions in social work will thus depend on whether society declares universalist or cultural-relativist values as more important. Both extreme positions have had 
disastrous results in the history of child protection and child welfare work, and the critical task for future interventions seems to be to strike the right balance between the two.

\section{Acknowledgements}

I am deeply grateful to Dr. Erica Righard, who generously supplied new references and offered helpful comments on an earlier draft of this paper. Also, I would like to thank the anonymous reviewers for the careful, critical reviews, and useful comments. This material is based upon work supported by the Swedish Research Council.

\section{Notes}

1. In Somalia they are called dhaqan celis, literally meaning 'cultural reimmersion' (Samatar, 2011, p. 509). In Abdile and Pirkkalainen (2011) the term is said to describe '[the one] bringing back corrupted Western habits and is in need of cultural reorientation' (p. 60).

2. The Swedish Board of Health and Welfare, which is the government agency supervising social work provided by regulatory authorities, frequently publishes information about rules and regulations. In one such information sheet the policy regarding so-called 'dumped' children was clarified; in practice leading to new guidelines among locally based governmental social workers (SoS 2004/2006). In addition, the Stockholm County Board issued a sharp warning on 9 January 2006 to the Social Services Committee in Nacka, responsible in the case of Ahmed and Nimo. According to the County Board, the committee had shown 'an astonishing lack of child perspective and sense of responsibility.' (Press release, at http://projektwebbar.ab.lst.se/templates/PressRelease 8230.asp)

Such warnings also work to regulate local practice.

3. Governmental bill 2005/06:JuU37. The new legislation was issued on July 1, 2006.

4. In Sweden in $2009,86 \%$ of all children aged 1-5 were placed in daycare centres, according to the Swedish government's website (regeringen.se).

5. Somali names are constructed thus: the first name is a boy's or a girl's name, the second name is the father's first name, the third name is the paternal father's first name.

6. 'Cousin' in the Somali family system is a flexible category: in any given social context the clan relatives closer to a person than any of the others present are those who will be called 'cousins' when introduced.

\section{Notes on contributor}

Johnsdotter, Sara (b. 1965). Professor at the Department of Social Work at the Faculty of Health and Society, specialized in Medical Anthropology after a PhD in Social Anthropology in 2002. Her research concerns the Somali group in Sweden, with a special focus on female circumcision and sexual health among Swedish Somalis.

\section{References}


Abdile, M. and Prikkalainen, P., 2011. Homeland perception and recognition of the diaspora engagement: The case of the Somali diaspora. Nordic Journal of African Studies, 20(1), pp. 48-70.

Agar, M.,1986. Speaking of Ethnography. Beverly Hills, CA: Sage.

Akesson, Lisa, Carling, J., and Drotbohm, H., 2012. Mobility, moralities and motherhood: Navigating the contingencies of Cape Verdean lives. Journal of Ethnic and Migrations Studies, 38(2), pp. 237-260.

Al-Sharmani, M., 2006. Living transnationally: Somali diasporic women in Cairo. International Migration, 44(1), pp. 55-77.

Al-Sharmani, M., 2010. Transnational family networks in the Somali diaspora in Egypt: Women's roles and differentiated experiences. Gender, Place and Culture, 17(4), pp. 499-518.

Andrijasevic, R. and Walters, W., 2010. The International Organization for Migration and the international government of borders. Environment and Planning D: Society and Space, 28 (6), pp. 977-999.

Baldassar, L., 2008. Missing kin and longing to be together: Emotions and the construction of co-presence in transnational relationships. Journal of Intercultural Studies, 29(3), pp. 247-266.

Balen, R. and Masson, H., 2008. The Victoria Climbié case: Social work education for practice in children and families' work before and since. Child and Family Social Work, 13, pp. 121-132.

Barn, R., 2007. 'Race', ethnicity and child welfare: A fine balancing act. British Journal of Social Work, 37, pp. 1425-1434.

Baumeister, R. F. and Muraven, M., 1996. Identity as adaptation to social, cultural, and historical context. Journal of Adolescence, 19(5), pp. 405-416.

Beck, U. and Beck-Gernsheim, E., 1995. The normal chaos of love. Cambridge: Polity Press.

Bernard, C. and Gupta, A., 2008. Black African children and the protection system. British Journal of Social Work, 38, pp. 476-492.

Bingham, J.K., 2013. Strengthening respect for family life and family unity in migration policy-making. QScience Proceedings, Family, Migration \& Dignity Special Issue, http://dx.doi.org/10.5339/qproc.2013.fmd.6

Bledsoe, C., 1990. 'No success without struggle': Social mobility and hardship for foster children in Sierra Leone. Man, 25(1), pp. 70-88.

Boddy, J., 1997. Writing Aman: The perils and politics of the popular book. Anthropology Today, 13(3), pp. 9-14.

Bornstein, M.H., Cultural approaches to parenting. Parenting: Science and Practice, 12, pp. 212-221.

Boyle, E.H. and Ali, A., 2009. Culture, structure, and the refugee experience in Somali immigrant family transformation. International Migration, 48(1), pp. 47-79.

Bryceson, D. F. and Vuorela, U., 2002. Transnational families in the twenty-first century. In: D. F. Bryceson and U. Vuorela, eds. The transnational family: New European frontiers and global networks. New York: Berg, pp. 3-30.

Coe, C., 2012. Growing up and going abroad: How Ghanaian children imagine transnational migration. Journal of Ethnic and Migrations Studies, 38(6), pp. 913-931. 
Dockery, A.M., 2010. Culture and wellbeing: The case of Indigenous Australians. Social Indicators Research, 99, pp. 315-332.

Engebrigtsen, A.D., 2007. Kinship, gender and adaptation processes in exile: The case of Tamil and Somali families in Norway. Journal of Ethnic and Migration Studies, 33(5), pp. 727-746.

Engebrigtsen, A.D., 2011. Ali's disappearance: The tension of moving and dwelling in the Norwegian welfare society. Journal of Ethnic and Migration Studies, 37(2), pp. 297313.

Falicov, C. J., 2005. Emotional transnationalism and family identity. Family Process, 44(4), pp. 399-406.

Falicov, C., 2007. Working with transnational immigrants: Expanding meanings of family, community and culture. Family Process, 46(2), pp. 157-171.

Furman, R., Negi, N., Schatz, M.C.S., and Jones, S., 2008. Transnational social work: Using a wraparound model. Global Networks, 8(4), pp.496 -503.

Gardner, K., 2012. Transnational migration and the study of children: An introduction. Journal of Ethnic and Migrations Studies, 38(6), pp. 889-912.

Goody, E. N., 1984. Parental strategies: Calculation or sentiment?: Fostering practices among West Africans. In: H. Medick and D. W. Sabean, eds. Interest and emotion: Essays on the study of family and kinship. Cambridge: Cambridge University Press, pp. 266-277.

Gray, M., Coates, J., and Bird, M.Y., 2010. Indigenous social work around the world: Towards culturally relevant education and practice. Farnham: Ashgate.

Gray, M. and Coates, J., 2010. From 'Indigenization' to cultural relevance. In: M. Gray, J. Coates, and M.Y. Bird, eds. Indigenous social work around the world: Towards culturally relevant education and practice. Farnham: Ashgate, pp. 13-25.

Griffith, D. J., 2002. Somali and Kurdish refugees in London: New identities in the diaspora. Aldershot: Ashgate.

Gullestad, M., 2003. Fighting for a sustainable self-image: The role of descent in individualized identification. Focaal - European Journal of Anthropology, 42, pp. 5162.

Ife, J., 2001. Local and global practice: Relocating social work as a human rights profession in the new global order. European Journal of Social Work 4(1), pp. 5-15.

Johnsdotter, S., 2002. Created by God: How Somalis in Swedish exile reassess the practice of female circumcision. Doctoral dissertation. Department of Social Anthropology, Lund University.

Kagitcibasi, C., 1996. Family and human development across cultures: A view from the other side. Mahwah, New Jersey: Lawrence Erlbaum.

Kagitcibasi, C., 2005. Autonomy and relatedness in cultural context: Implications for self and family. Journal of Cross-Cultural Psychology, 36(4), pp. 403-422.

Korbin, J. E. ed., 1981. Child abuse and neglect: Cross-cultural perspectives. Berkeley: University of California Press.

LeVine, S. and LeVine, R., 1981. Child abuse and neglect in Sub-Saharan Africa. In J. E. Korbin, ed. Child Abuse and Neglect: Cross-Cultural Perspectives. Berkeley: University of California Press, pp. 35-55.

Lincoln, Y.S., and Guba, E.G., 1985. Naturalistic inquiry. Newbury Park, CA: Sage. 
Lyons, K., 2006. Globalization and social work: International and local implications. British Journal of Social Work, 36, 365-380.

Ní Laoire, C., Carpena-Méndez, F., Tyrrell, N., and White, A., 2010. Introduction: Childhood and migration - mobilities, homes and belongings. Childhood, 17(2), pp. 155-162.

Olwig, K.F., 2012. The care chain, children's mobility and the Caribbean migration tradition. Journal of Ethnic and Migration Studies 38(6), pp. 933-952.

Orellana, M.F., Thorne, B., Chee, A., and Lam, W.S.E., 2001. Transnational childhoods: The participation of children in processes of family migration. Social Problems, 48(4), pp. 572-591.

Peutz, N., 2006. Embarking on an anthropology of removal. Current Anthropology, 47(2), pp. 217-238.

Raman, S. and Hodes, D., 2012. Cultural issues in child maltreatment. Journal of Paediatrics and Child Health, 48, pp. 30-37.

Renzaho, M. N., Green, J., Mellor, D. and Swinburn, B., 2011. Parenting, family functioning and lifestyle in a new culture: The case of African migrants in Melbourne, Victoria, Australia. Child and Family Social Work, 16, pp. 228-240.

Rousseau, C., Said, T.M., Gagné, M.J., and Bibeau, G., 1998. Resilience in unaccompanied minors from the north of Somalia. Psychoanalytic Review, 85(4), pp. 615-37.

Samatar, A.I., 2011. Book Review: The Early Morning Phone Call: Somali Refugees' Remittances, by Anna Lindley. Review of African Political Economy 38(129), pp. 508509.

SVT, 2005. Dumpad i Afrika [Dumped in Africa]. Documentary aired September 13, 2005, by the Swedish national broadcasting company SVT.

SVT website, 2005. Posts by viewers at the official website of the Swedish national broadcasting company SVT. forum.svt.se

Therborn, G., 2004. Between sex and power: Family in the world 1900-2000. London: Routledge.

Thorpe, D., 1994. Evaluating child protection. Buckingham: Open University Press.

Tiilikainen, M., 2007. Continuity and change: Somali women and everyday Islam in the diaspora. In: A.M. Kusow and S. Bjork, eds. From Mogadishu to Dixon: The Somali diaspora in a global context. Trenton, NJ: The Red Sea Press, pp. 207-230.

Tiilikainen, M., 2011. Failed disaspora: Experiences of dhaqan celis and mentally ill returnees in Somaliland. Nordic Journal of African Studies 20(1), pp. 71-89.

Trygged, S., 2010. Balancing the global and the local: Some normative reflections on international social work. International Social Work, 53(5), pp. 644-655.

Webb, S.A., 2009. Against difference and diversity in social work: the case of human rights. International Journal of Social Welfare 18(3), pp. 307-316.

White, A., Ní Laoire, C., Tyrrell, N., and Carpena-Méndez, F., 2011. Children's roles in transnational migration. Journal of Ethnic and Migrations Studies, 37(8), pp. 11591170.

Williams, C. and Soydon, H., 2005. 'When and how does ethnicity matter? A crossnational study of social work responses to ethnicity in child protection cases'. British Journal of Social Work, 35, pp. 901-920. 
Published in The European Journal of Social Work, 2013

Winter, K., 2011. The UNCRC and Social Workers' Relationships with Young Children. Child Abuse Review 20(6), pp. 395-406. 